\title{
Development of Smart Adventure Games to Improve the Readiness of the Initial Ability of Reading, and Writing (CALIS) on Early Childhood
}

\author{
Linda Dwiyanti $^{1 凶}$, Rosa Imani Khan ${ }^{2}$, Epritha Kurniawati ${ }^{3}$ \\ Prodi PG-PAUD, FKIP, Universitas Nusantara PGRI Kediri
}

\begin{abstract}
Based on these circumstances, this study aims to develop an appropriate game to improve readiness of the initial ability of reading, and writing on early childhood called "Smart Adventure". This game can help children to learn the ability of the initial reading and writing with a fun method (play) and in accordance with the characteristics and stages of early childhood development. This study used a qualitative and quantitative approach (mix method) with "Borg and Gall" research and development model. The procedures used include: research and information collecting, planning, develop preliminary form of product, preliminary field testing, main product revision, main field testing, operational product revision, operational field testing, final product revision, and dissemination and implementation. The results of this study indicate the effectiveness and usefulness of the Smart Adventure game product on the ability to reading and writing early childhood.
\end{abstract}

Keywords: Smart Adventure, Reading and Writing (CALIS), Early Childhood.

\begin{abstract}
Abstrak
Penelitian ini bertujuan untuk mengembangkan sebuah permainan yang tepat untuk meningkatkan kesiapan belajar membaca dan menulis permulaan anak usia dini, yakni "Smart Adventure". Permainan ini dapat membantu anak untuk belajar kemampuan membaca dan menulis permulaan dengan metode yang menyenangkan (bermain) dan sesuai dengan karakteristik serta tahapan perkembangan anak usia dini. Penelitian ini menggunakan pendekatan kualitatif dan kuantitatif (mix method) dengan model penelitian dan pengembangan "Borg and Gall". Prosedur yang digunakan antara lain: research and information collecting, planning, develop preliminary form of product, preliminary field testing, main product revision, main field testing, operational product revision, operational field testing, final product revision, and dissemination and implementation. Hasil dari penelitian ini adalah permainan Smart Adventure terbukti efektif dan memiliki kebermanfaatan dalam meningkatkan kesiapan belajar membaca dan menulis permulaan anak usia dini.
\end{abstract}

Kata Kunci: Smart Adventure, Membaca dan Menulis Permulaan, Anak Usia Dini

@ Jurnal Obsesi Prodi PG-PAUD FIP UPTT 2018

$\triangle$ Corresponding author :

Address : Ngangkatan, Rejoso, Nganjuk

ISSN 2356-1327 (Media Cetak)

Email : $\underline{\text { lindadwiyanti@unpkediri.ac.id }}$

ISSN 2549-8959 (Media Online) 


\section{INTRODUCTION}

Improving human quality is the key to successful development of a nation. Human resource development is a continuous process from an early age. Early childhood is a child in the age range of birth up to six years, which is the nation's next generation that has the potential to grow and develop optimally (Ministry of National Education in Nuraini and Sujiono, 2010). Efforts to develop the potential of early childhood are carried out through the implementation of educational institutions namely Early Childhood Education which is the most basic education occupying a very strategic position in the development of human resources. The potential of intelligence and the basics of one's behavior are formed in this age range. So important that this early age is often referred to the golden age (Noorlaila, 2010). The National Education System Law No. 20 of 2003 Chapter I, Article 1, Item 14 explains that early childhood education is aimed at children from birth to six years of age which is carried out through the provision of educational stimuli to assist physical and spiritual growth and development so that children are ready to receive further education. Furthermore, in Article 4 Paragraph 5 of the Implementation Principle, it is explained that education is carried out by developing culture, writing and counting for all citizens. The introduction and learning of reading, and writing (calis) commenced at the beginning of Early Childhood Education (PAUD). The introduction of the beginning of reading, and writing (calis) is an aspect of developing children's interrelated and inseparable abilities. Early age is the most appropriate time for individuals to receive stimulations. According to Pebriana (2017: 140) language development in early childhood is one of the factors that influence children's cognitive development. The more children grow and develop and begin to be able to understand the environment, the development of language will also develop from a simple level to the most complex level.

The facts of the findings from field observations of kindergartens in Kediri region, there are several problems, namely: 1) the learning strategy of Calis in kindergarten is not in accordance with the characteristics and stages of children's development; 2) There are demands from parents who want their children have ability of calis after graduating from kindergarten due to the selection test of majority elementary school; 3) Calis learning activities in kindergarten tend to use paper and pencil and this is not in accordance with the nature of kindergarten namely playing while learning. This seems to be in line with the opinion of Aulina (2012) explained that there are many elementary schools, especially primary schools which make the Calis ability as a test to select new students for elementary school. This encourages educational institutions and parents to actively teach Calis skills with learning methods in elementary schools that are not in accordance with the stages of child development. It makes PAUD, which should be a fun learning place where children can play and make friends, starts to turn into a children's institution that only meets the target of the calis ability. This activity resulted in assignments that must be completed at home or commonly referred to as homework as the learning process in elementary school.

Sugiono and Kuntjojo (2016) in a similar study, also found the fact that there were problems during field observations. In the implementation or application of playing activities in kindergarten, there were still some teachers who considered playing not as the main important activities in class and not as a method of development. Secondly, playing activities are only carried out to develop certain abilities and have not been directed to develop various fields of development. According to Sugiono and Kuntjojo (2016), early childhood have certain characteristics in learning. One of the characteristics of how children learn is 
that children learn through play. Based on these characteristics, playing while learning and learning while playing is applied in early childhood learning. The game is a means to measure children's abilities and potential. Children will master various kinds of objects, understand their properties and events that take place in their environment Mutiah (Aisyah, 2017).

White (2012: 7) stated that play build the foundation for lifetime of learning. Play is adapted to the children's development starting from playing while learning (the playing aspect is bigger) and to learning while playing (the learning aspect is bigger).

Playing for children can bring joy and also become a learning process that develop various aspects. This statement is also in accordance with Badu's (2011) study, that playing is the process of preparation to enter the next world. Playing is a way for children to gain knowledge about everything. Playing will make children to explore, train physical growth and imagination, and provide broad opportunities to interact with other friends, introduce simple concepts and develop language skills and words, thus it makes learning as a very enjoyable learning activity.

The activity of introducing and enhancing Calis for early childhood can be done through games that will certainly be more effective because the world of children is all about playing. Aspects of children's development can be grown optimally through playing activities. Based on several studies and background problems, it is necessary to develop a game called Smart Adventure Games to improve initial Calis learning on early childhood readiness. Smart adventure is a game of adventure using artificial media that describes a beautiful park where children will interact directly with the environment that is created and learning is more fun and meaningful for children. It is expected that through this game, children will receive the Calis learning concept directly and pleasantly. How can the development of
Smart Adventure Games improve initial Calis learning on early childhood readiness? This statement is the problem statement in this study.

\section{METHOD}

This study used quantitative approach. Based on its objectives, this research is a research and development research. The chosen development research model is an educational research and development model developed by Borg and Gall (2003). According to Borg and Gall, "educational research and development ( $\mathrm{R} \& \mathrm{D}$ ) is a process used to develop and validate educational production".

The concept of this research is more precisely interpreted as a development effort that is simultaneously accompanied by efforts to validate it. Borg and Gall (2003) states that the development research procedure basically consists of two main objectives, namely: developing products and testing the effectiveness of products in achieving goals. Research steps taken include: a) Research and information gathering; b) Planning; c) Development of the initial draft of the product; d) Evaluation; e) Small group trials; f) Product revision; g) large group trials; h) Final revision; i) The final product. In the small group trial phase (point g), the researcher used the Wilcoxon theory in Sugiono (2014) "signed-rank test is a non-parametric statistical hypothesis test used to compare two related samples, matched samples, or repeated measurements on a single sample to assess whether their population mean ranks differ" ( $t$-test), as an analysis test.

The research subjects were the children of B Dharma Wanita Betet TK Kediri group in the 2017/2018 school year and the B RA group children Al Falah Pagu Kediri. This research was carried out at the beginning of June 2017 - August 2018. Data collection instruments in this study were validation questionnaire and assessment sheet of children's learning outcomes on small and large groups test. 
Data analysis technique in this study was qualitative descriptive techniques on the model testing and validation. While on the test of the effectiveness of the Smart Adventure game model, it was used inferential statistical techniques, especially the Paired-Samples T Test.

\section{RESULT AND DISCUSSION}

The results of preliminary studies conducted in several kindergartens in Kediri Raya have several facts, namely: 1) Kindergarten children learn calis not in accordance with their characteristics and stages of development; 2) There are demands from parents who want their children to be smart on calis after graduating from kindergarten because they prepare to join elementary school, with the majority selection test is Calis test; 3 ) Calis learning activities in kindergarten tend to use paper and pencil, this is not in accordance with the nature of PAUD namely playing while learning. This Smart Adventure game was designed after conducting in-depth theoretical studies and through a validation process from several experts followed by several trials in the field. This Smart Adventure game has been refined after going through these processes to produce a product that is ready for widespread use. The elaboration of the results of data analysis in this study are as follows:

\section{Small Group Test Results}

Based on the results of the evaluation of the trial of the Smart Adventure Game to improve Calis initial learning readiness in small groups, it resulted product revisions: (1) The media used in this game seemed interesting and easy to play by children, but in terms of durability, this game was broken easily so it needs to be replaced; (2) Children are seen enjoying the calis learning process through this game, but considering the number of children in one class, it is quite needs to be considered again about the duration of the game, so that children do not feel too bored while waiting for their turn to play. After several improvements, the revised product was re-tested in large groups.

\section{Large Group Trial Results}

After large group test, the minus points that were previously found in this game have no longer appeared. Based on the results of the large group trial, it was found that: (1) The media used in this game is safe and durable for early childhood use. In addition, colorful media appearances can attract children to learn initial Calis through Smart Adventure Game. The characteristics of the media in this game are in accordance with early childhood learning models; (2) Clarity of game procedures makes it easier for children to play this game. The steps in this game are in accordance with the stages of early childhood development; (3) This Smart Adventure game has proven to be able to increase Calis initial learning readiness in early childhood. Children who start learning Calis through this game have a better Calis ability compared to their abilities before playing this game.

The results of the preliminary study and the research that has been carried out are summarized as follows: (1) Many schools implement learning strategies that are not in accordance with the characteristics and learning needs for early childhood; (2) The Smart Adventure Game Model is prepared by being preceded by in-depth theoretical study and tested in small groups and large groups. From this process, there were some improvements in this game. The results of expert validation concluded that the Smart Adventure Game proved to be interesting and effective to improve Calis early childhood learning readiness.

The conclusion from the results of the trial of the Smart Adventure Game in a small group is that, it is necessary to replace the materials and trim the duration of the game time. While the conclusion of the results of the Smart Adventure Game trials in large group is the negative points 
of this game that appears on small group trial is no longer appearing.

\section{Smart Adventure Game Effectiveness Test}

Based on the results of the small group and large group trials that have been conducted, the Smart Adventure Game is tested for its effectiveness through an experimental process. Small group trials were conducted on $9^{\text {th }}$ and $10^{\text {th }}$ April 2017 on 20 children of B3 TK Dharma Wanita Betet Kediri Group. While the large group trials were conducted on $8^{\text {th }}$ and $9^{\text {th }}$ May 2017 on 20 children of B2 Group TK Dharma Wanita Betet Kediri and on $26^{\text {th }}$ and $27^{\text {th }}$ April 2017 on 19 children of RA Al Falah B1 Group Kediri Ceiling.

The initial ability to read, and write of the children was assessed before and after experiment by the class teacher. The results of the assessment before and after this experiment were compared. The Wilcoxon Test was used to analyze the experimental data during small group trial because the number of samples was less than $30(n<30)$ and did not use the control class and see the effect of the Smart Adventure game on children before and after it was applied. To analyze the experimental data during a large group trial, it was used Paired-Samples T Test analysis.

For the results of the analysis of experimental data on small group test on the initial ability to read and write, the average score of these abilities before being given an action of 14.65 and after being given an action of 15.45 . This means that the initial ability to read and write after being given an action in the form of a Smart Adventure Game is greater than before being given an action. From the results of the analysis, it also obtained the mean rank score of 6.80 and the positive mean score is greater than the negative mean rank. This means that the application of the Smart Adventure game has been proven to improve children's initial reading and writing skills. From the results of the analysis of experimental data on large group test on the initial ability of reading and writing of children, from the calculation of Paired-Samples $\mathrm{T}$ Test, it can be seen that the acquisition of test results is 4.886 and the difference in mean score is 1.821 and by considering the Sig score of 0.0001 , it can be said that there is a significant difference between the average score of children in the experimental group and the average score in the control group. The mean score in the experimental group is 14.51 and in the control group is 12.69 . The difference in the mean score indicates that there is a positive and significant effect on the application of the Smart Adventure Game on the initial ability to read and write of children.

As for the results of the analysis of experimental data when testing large groups on the ability of preliminary counting of children, from the results of the Paired-Samples T Test can be seen that the acquisition of test results is 4.842 and the difference in mean score is 1.2282 and by considering the Sig score of 0.0001 it can be said that there is a significant difference between the average score of children in the experimental group and the mean score in the control group. The mean score in the experimental group was 10.74 and in the control group was 9.46. The difference in the mean score indicates that there is a positive and significant influence on the application of the Smart Adventure Game on the initial ability to calculate of children.

Table. 4.1 significant difference between Experimen and control class

\begin{tabular}{|c|c|c|c|c|c|}
\hline $\begin{array}{c}\text { Kelomp } \\
\text { ok }\end{array}$ & $\begin{array}{c}\text { N } \\
\text { (banya- } \\
\text { nya } \\
\text { sampel) }\end{array}$ & Mean & $\begin{array}{c}\text { Perbe- } \\
\text { daan } \\
\text { Mean }\end{array}$ & t-test & $\begin{array}{c}\text { Sig. (2- } \\
\text { tailed) }\end{array}$ \\
\cline { 1 - 2 } $\begin{array}{c}\text { Eksper } \\
\text { imen }\end{array}$ & 39 & 14,51 & 1,821 & 4,886 & 0,0001 \\
\cline { 1 - 2 } $\begin{array}{c}\text { Kontro } \\
1\end{array}$ & 39 & 12,69 & & \\
\hline
\end{tabular}




\section{Mean Kemampuan Calis}

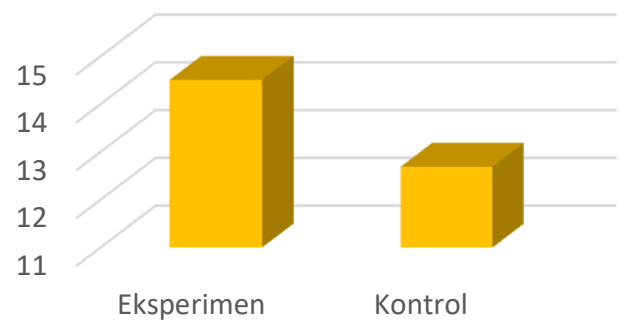

Grafik 4.1 significant difference between Experimen and control class

\section{Use of smart adventure games in early} childhood learning.

The results of the data analysis of the usefulness of the use of smart adventure games in early childhood learning based on the table can be concluded that the total value of fifteen items is 252 which means the application of the "Smart Adventure" game is very effective to be applied in kindergarten.

\section{CONCLUSION}

Based on the results of the research from the development of the Smart Adventure game, it was concluded that the development of "Smart Adventure" game based on the results of data analysis in the effectiveness test test can be expressed as an effective game to improve early childhood reading and writing skills, and the results of data analysis also showed the usefulness of games in learning early childhood. Theoretically, the results of this study are in line with the theory proposed by White (2012: 7), which states that "play build the foundation for lifetime of learning" which means that learning is a lifelong process that the foundation is at playing at an early age.

\section{ACKNOWLEDGEMENT}

The researcher would like to thank to various parties who contributed to the success of this research, especially: 1) Ministry of Research, Technology and Higher Education of Republic of Indonesia; 2) Nusantara PGRI Kediri University Institute; 3) Institutions of TK Dharma Wanita Betet Kediri and RA Al-
Falah Pagu Kediri and all parties involved in this study

\section{REFERENCES}

Aisyah, A. (2017). Permainan Warna

Berpengaruh Terhadap Kreativitas

Anak Usia Dini. Jurnal Obsesi:

Pendidikan Anak Usia Dini, 1(2).

Aulina, N.A. 2012. Pengaruh Permainan dan Penguasaan Kosakata terhadap Kemampuan Membaca Permulaan Anak Usia 5-6 Tahun. Jurnal Pedagogia. 1 (2): 131 - 143.

Badu, R. 2011. Pengembangan Model Pelatihan Permainan Tradisional Edukatif Berbasis Potensi Lokal Dalam Meningkatkan Kemampuan dan Keterampilan orang tua Anak Usia Dini Di PAUD Kota Gorontalo. Jurnal Penelitian dan Pendidikan. 8 (1): $70-77$.

Borg \& Gall. 2003. Education Research. Allyn and Bacon, New York.

Noorlaila, I. 2010. Panduan Lengkap Mengajar PAUD. Pinus Book Publisher, Yogyakarta.

Nurani, Y dan B. Sujiono. 2010. Bermain Kreatif Berbasis Kecerdasan Jamak. PT Indeks, Jakarta.

Sugiono. 2014. Metode Penelitian Pendidikan Pendekatan Kuantitatif, Kualitatif dan RnD. Bandung: Alfabeta.

Pebriana, Putri Hana. 2017. Analisis Kemampuan Berbahasa dan Penanaman Moral pada Anak Usia Dini melalui Metode Mendongen. Online. Diakses tanggal 15 Oktober 2018. Jurnal Obsesi: Pendidikan Anak Usia Dini. 1 (2): 139-147.

Sugiono dan Kuntjojo. 2016. Pengembangan Model Permainan Pra-Calistung Anak Usia Dini. Jurnal Pendidikan Anak Usia Dini. 10 (2): 255- 276

White, Rachel E. 2012. The Power Of Play: A Research Summary on Play and Learning. Online. St. Paul: $\mathrm{MCM}$ 